\title{
1890-1929 年の銀行建物に関する研究
}

\author{
五大銀行の建物外観に共通する建築要素について \\ A STUDY ON BANK BUILDINGS CONSTRUCTED BETWEEN 1890 AND 1929
}

Common architectural elements in the external appearances of the buildings of Japan's five major banks

\author{
中村 弘*, 篠崎 道彦** \\ Hiroshi NAKAMURA and Michihiko SHINOZAKI
}

\begin{abstract}
The history of bank buildings in Japan commenced with the establishment of the First National Bank in 1872. To date, only minimal research on the historical changes in the bank buildings constructed between 1872 and present day has been conducted. Focusing on building exteriors, this study aims to examine the common architectural elements in the bank buildings constructed between 1890 and 1929. This study serves as an introductory account of the historical changes in the bank buildings constructed between 1872 and present day.
\end{abstract}

Keywords : Bank building, Common architectural elements, External appearance, Transition in bank architecture 銀行建物，共通要素，外観，銀行建物の変遷

1. はじめに

\section{1. 研究の背景}

1872 年に東京府皃町に建設された第一国立銀行（三井組八ウス） から始まった銀行建物は、明治期から現在までの間にどのような変 化をしてきたのか。銀行は、明治以降、資本主義社会の成立に中心 的な役割を果たしてきた。同時に、銀行にとって重要な経営資源で ある銀行建物（本店・支店）は、国内近代建築においても嚆矢とし ての役割を担っていたといえる ${ }^{1)}$ 。国内銀行の草創期である明治期 から大正期の銀行建物について設計者たちは、銀行業務の信頼性や 資金力を伝えること、安心、堅実、威厳などの銀行イメージを表現 することなどを提唱していた ${ }^{2)}$ 。1928 年施行の銀行法により 銀行業 務が変化し、戦争を経た 1950 年代以降には、銀行らしい建物と銀行 らしからぬ建物について、今後の銀行建物の方向性についてなどの 議論がされていた ${ }^{3)}$ 。その後 1996 年からの金融制度改革による銀行 業のパラダイムシフトにより、さらに銀行建物は変化してきている。 そして銀行草創期に銀行らしいとされた建物が現在では見られなく なってきている。そこで 1872 年から 140 年以上に及ぶ銀行という一 つの用途の建物について、通史的な変遷を概観したい事が本研究の 背景である。歷史的な意匠と思潮を理解する事で新しいデザインを 創出する観点から、今後の銀行建物に示唆を得るための端緒とする。

\section{2. 既往研究}

これまでも銀行建物については多くの研究がなされている。特定
地域の銀行に関する研究 ${ }^{4)}$ 、建築家個人の研究における作品として の銀行 ${ }^{5)}$ 、個別の銀行建物に関寸る研究 ${ }^{6)}$ 、銀行建物の保存や解体 および用途変更に関する研究 ${ }^{7)}$ 、都市計画や街並みにおける銀行を 対象とした研究 ${ }^{8)}$ などがある。また、経済地理学および人文地理学 では銀行店舗の配置、店舗と地域的な関連についての研究 ${ }^{9)}$ がなさ れている。そして経済学においては銀行に関する多くの時期、全国 および地域、また通史的網羅的に多くの研究がなされている。しか し銀行建物に関するこれまでの研究は、対象とする建物、地域、時 期などが特定の範囲に限られており、通史的に銀行建物の変化を明 らかにした研究はなされてない。

\section{2. 研究の目的と方法}

\section{1. 研究の目的}

銀行建物の通史的な変遷を明らかにするために、本研究の目的を、 まず国内の初期の銀行建物とはどのような建物だったのかを明らか にすることとする。そこで本研究では、国内の商業銀行の始点であ る ${ }^{10)}$ 銀行条例が制定された 1890 年から、業法上銀行の公衆化の始 まりとされる ${ }^{10)}$ 銀行法が施行された（1928 年）翌年の 1929 年まで 注 1) の銀行建物を対象として、銀行建物の外観に着目して、銀行建 物に共通寸る建築要素について考察する。1872 年から現代までの銀 行建物全体の変遷を通史的に明らかにするための緒論とすることが 本研究の意義である。

\footnotetext{
* 芝浦工業大学大学院 大学院生 ·修士 (技術経営)

Grad. Stud., Graduate School of Engineering and Science, Shibaura Institute of Technology, M. M.O.T.

** 芝浦工業大学デザイン工学部 教授・工博

Prof., Dept. of Engineering and Design, Shibaura Institute of Technology, Dr.Eng.
} 


\section{2. 研究の方法}

\section{2. 1. 研究対象}

本研究では、以下の三点より、五大銀行 11) と呼称されていた三 井、三菱、安田、住友、第一銀行を対象とする。(1)現時点で存続さ れていて ${ }^{12)} 、$ 銀行業務、店舗沿革などについて設立から現在までの 変遷を銀行資料で確認できる。(2)明治期以来、他の銀行に比べて金 融上大きな影響力を及ぼしてきている ${ }^{13)}(1928$ 年の全国普通銀行に 対する五行シェアは預金 $33.5 \%$ 、貸出 $25.6 \%$ 注 2) $)$ 。(3)銀行建物の建 設について、本部の営繥担当部署が管理して全国展開しているため 設計概念・仕様が同質化されていると考えられる。その他、建物の 設計・施工についても当時の国内主要な組織・企業が担当している。 そして、五銀行の国内銀行業務におけるシェアおよび影響力から、 業務用の建物についても星引的な影響を及ぼしていたと推測する。

研究対象の期間は、国内銀行のあり方を発券銀行から商業銀行 (普 通銀行） 一と転換させる始点としての銀行条例が制定された 1890 年から、業法上銀行の公衆 (大衆) 化が始まる銀行法施行（1928 年） の翌年 1929 年 (竣工・開業建物) までとする。銀行建物は、銀行の 業務・営業（取引）を目的とした建物であるため、銀行業務の変化 に影響を受けると考えられる。したがって、銀行業務の基準となる 業法制度の画期を銀行建物の画期として研究対象期間を設定した。 研究対象期間の銀行全体の一輪郭として、1890～1929 年の五銀行の 店舗数および国内銀行の銀行数と全店舗数を Table $1^{\text {注 }}$ 3) に示す。

Table 1 Quantity of five bank branches

\begin{tabular}{|c|c|c|c|c|c|c|c|c|c|c|c|c|c|c|}
\hline \multirow{2}{*}{ 年 和暦 } & \multicolumn{2}{|c|}{ 三井 } & \multicolumn{2}{|c|}{ 菱 } & \multicolumn{2}{|c|}{ 安田 } & \multicolumn{2}{|c|}{ 住友 } & \multicolumn{2}{|c|}{ 第一 } & \multicolumn{2}{|c|}{ 五行計 } & \multirow{2}{*}{ 全銀行数 } & \multirow{2}{*}{ 全虞舒数 } \\
\hline & 店鐡数 & & 店解数 & 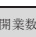 & & & & & & & 店涪数 & 田業䝮 & & \\
\hline $1890 \mathrm{M} 23$ & 31 & & & & 5 & 1 & & & & & 36 & 1 & 353 & 504 \\
\hline $1891 \mathrm{M} 24$ & 31 & & & & 5 & & & & & & 36 & 0 & 388 & 537 \\
\hline $1892 \mathrm{M} 25$ & 26 & & & & 6 & 2 & & & - & & 32 & 2 & 405 & 415 \\
\hline $1893 \mathrm{M} 26$ & 33 & 1 & & & 8 & 2 & & & & & 41 & 3 & 703 & \begin{tabular}{|l|l|}
1,041 \\
\end{tabular} \\
\hline $1894 \mathrm{M} 27$ & 23 & & & & 8 & & - & & - & & 31 & 0 & 865 & 1,274 \\
\hline $1895 \mathrm{M} 28$ & 23 & & 5 & 4 & 8 & & 5 & 5 & & & 41 & 9 & 1,013 & 1,452 \\
\hline $1896 \mathrm{M} 29$ & 24 & 1 & 5 & & 9 & 1 & 5 & & 6 & & 49 & 2 & 1,277 & \begin{tabular}{|l|l|}
2,102 \\
\end{tabular} \\
\hline $1897 \mathrm{M} 30$ & 20 & & 5 & & 9 & 1 & 9 & 4 & 6 & & 49 & 5 & 1,505 & 2,501 \\
\hline 1898 M31 & 21 & 1 & 5 & & 9 & & 9 & & 8 & 2 & 52 & 3 & 1,752 & 3,126 \\
\hline 1899 M32 & 20 & & 3 & 1 & 12 & 4 & 11 & 2 & 9 & 1 & 57 & 8 & 1,943 & 3,654 \\
\hline $1900 \mathrm{M} 33$ & 20 & & 5 & & 14 & 2 & 12 & 1 & 10 & 1 & 61 & 4 & 2,272 & \begin{tabular}{|l|l|}
4,471 \\
\end{tabular} \\
\hline 1901 M34 & 19 & & 5 & & 14 & & 14 & 2 & 10 & & 62 & 2 & 2,359 & $\begin{array}{l}, 370 \\
\end{array}$ \\
\hline 1902 M35 & 19 & & 5 & & 15 & 1 & 15 & 1 & 11 & 1 & 65 & & 2,324 & 4,342 \\
\hline $1903 \mathrm{M} 36$ & 16 & & 5 & & 14 & 1 & 16 & 1 & 11 & & 62 & 2 & 2,275 & \begin{tabular}{|l|l|}
4,314 \\
\end{tabular} \\
\hline $1904 \mathrm{M} 37$ & 16 & & 5 & & 16 & 2 & 16 & & 11 & & 64 & 2 & 2,227 & 4,228 \\
\hline $1905 \mathrm{M} 38$ & 14 & & 5 & & 19 & 3 & 17 & 1 & 11 & 1 & 66 & 5 & 2,230 & 4,299 \\
\hline $1906 \mathrm{M} 39$ & 14 & & 5 & & 21 & 1 & 17 & & 11 & & \begin{tabular}{|l|l|}
68 \\
\end{tabular} & 1 & 2,210 & \begin{tabular}{|l|l|l|}
4,377 \\
\end{tabular} \\
\hline $1907 \mathrm{M} 40$ & 13 & & 5 & & 21 & & 17 & & 11 & & 67 & 0 & 2,194 & \begin{tabular}{|l|l|} 
\\
\end{tabular} \\
\hline $1908 \mathrm{M} 41$ & 13 & & 5 & & 21 & & 17 & & 11 & & 67 & 0 & 2,172 & 4,584 \\
\hline $1909 \mathrm{M} 42$ & 15 & 2 & 5 & & 21 & & $\begin{array}{ll}18 \\
\end{array}$ & 1 & 11 & & 70 & 3 & $\begin{array}{l}2,152 \\
\end{array}$ & \begin{tabular}{|l|l|l|l}
4,593 \\
\end{tabular} \\
\hline $1910 \mathrm{M} 43$ & 15 & & 5 & & 22 & 1 & 18 & & 11 & & 71 & 1 & 2,144 & \begin{tabular}{|l|l|}
4,649 \\
\end{tabular} \\
\hline $1911 \mathrm{M} 44$ & 15 & 1 & 6 & 1 & 22 & & 18 & & 11 & & 72 & 2 &, 143 & 4,783 \\
\hline $1912 \mathrm{M} 45$ & 15 & & 6 & & 22 & & 20 & 2 & 18 & 7 & 81 & 9 & 2,151 & 5,003 \\
\hline $\begin{array}{ll}1913 & \mathrm{~T} 2\end{array}$ & 15 & & 6 & & 22 & & 21 & 1 & 20 & 2 & 84 & 3 & 2,155 & \begin{tabular}{|l|l|}
5,259 \\
\end{tabular} \\
\hline 1914 T3 & 15 & & 5 & & 22 & & 22 & 1 & \begin{tabular}{|l|}
20 \\
\end{tabular} & & 84 & 1 & 2,153 & 5,453 \\
\hline $1915 \quad \mathrm{~T} 4$ & 14 & & 6 & 1 & 22 & & 23 & 1 & 22 & 2 & 87 & 4 & 2,149 & 5,518 \\
\hline $\begin{array}{ll}1916 & \text { T5 }\end{array}$ & 15 & 1 & 6 & & 22 & & 28 & 1 & 23 & 3 & 94 & 5 & 2,140 & 5,808 \\
\hline $1917 \mathrm{~T} 6$ & 16 & 1 & 8 & 1 & 22 & & 29 & & \begin{tabular}{|l|}
25 \\
\end{tabular} & 2 & 100 & 4 & \begin{tabular}{|l|}
2,110 \\
\end{tabular} & \begin{tabular}{|l|l|}
5,929 \\
\end{tabular} \\
\hline $1918 \quad \mathrm{~T} 7$ & 19 & 3 & 9 & 1 & 22 & & 35 & 3 & 25 & 1 & 110 & 8 & 2,085 & 6,177 \\
\hline $\begin{array}{ll}1919 & \text { T8 } \\
\end{array}$ & 19 & & 10 & 1 & 23 & 1 & 37 & 2 & 26 & 1 & 115 & 5 & \begin{tabular}{|l|}
2,048 \\
\end{tabular} & 6,528 \\
\hline $\begin{array}{ll}1920 & \mathrm{~T}\end{array}$ & 19 & & 13 & 1 & 24 & 1 & 37 & & 27 & 1 & 120 & 3 & \begin{tabular}{|l|}
2,035 \\
\end{tabular} & \begin{tabular}{|l|l|}
6,979 \\
\end{tabular} \\
\hline $1921 \mathrm{~T} 10$ & 18 & & 13 & & 24 & & 42 & 5 & 27 & & 124 & 5 & 2,011 & 7,304 \\
\hline $1922 \mathrm{~T} 11$ & 20 & 2 & 15 & 3 & 26 & 1 & 43 & 1 & 27 & & 131 & 7 & 1,975 & 7,711 \\
\hline $1923 \quad \mathrm{~T} 12$ & 20 & & 16 & 1 & 211 & 1 & 45 & 2 & 31 & 4 & 323 & 8 & 1,870 & 7,734 \\
\hline $1924 \mathrm{~T} 13$ & 22 & 2 & 18 & 2 & \begin{tabular}{|l|l|}
216 \\
\end{tabular} & 4 & 54 & 8 & 32 & 1 & 342 & 17 & 1,795 & 7,720 \\
\hline 1925 T14 & 23 & 1 & 18 & & \begin{tabular}{|l|l|}
180 \\
\end{tabular} & 3 & 59 & 5 & 32 & & 312 & 9 & 1,700 & \begin{tabular}{|l|l|}
8,689 \\
\end{tabular} \\
\hline 1926 T15 & 23 & & 18 & & 180 & 1 & 66 & 8 & 33 & 1 & 320 & 10 & 1,574 & 7,549 \\
\hline 1927 S2 & 23 & & 19 & 1 & 17 & 2 & 74 & 7 & 51 & 18 & 344 & 28 & \begin{tabular}{|l|}
1,424 \\
\end{tabular} & 7,306 \\
\hline $1928 \quad \mathrm{~S} 3$ & 24 & 1 & 19 & & 156 & 1 & 76 & 1 & 52 & 1 & 327 & 4 & \begin{tabular}{|l|}
1,159 \\
\end{tabular} & 6,779 \\
\hline $1929 \quad S 4$ & 24 & & 24 & 2 & \begin{tabular}{|l|l|}
154 \\
\end{tabular} & & 79 & 4 & 52 & & 333 & 6 & 1,003 & 8,0 \\
\hline 業数合 & & & & & & & & & & & & & & \\
\hline
\end{tabular}

\section{2. 2. 研究方法}

1890〜1929 年に五銀行が国内で新たに開業（新築・建替え）した 支店・出張所は 194 件注3) (Table 1：三井 17、三菱 20、安田 37、 住友 70 、第一 50 。開店時は出張所で後に支店に昇格した店舗を含 む。）である。そして 1890１929 年に五銀行として建設された銀行 建物のうち、銀行史 ${ }^{14)}$ 、建築文献 ${ }^{15)}$ から図面、外観、内観に関す る資料が確認できた 121 件（Table 2：三井 13、三菱 10、住友 45 、 安田 26、第一 27）を調查対象とする。統合・合併前の銀行建物（店 舗）として建設され、統合・合併により五銀行の店舗となった建物 は調査対象には含まない。また、1890〜1894 年の銀行建物について は事例を確認できる資料がなかった。なお、1890〜1894 年に五銀行 で開業された支店・出張所は 6 件（三井 $1 、$ 安田 5）である。

Table 2 List of bank building

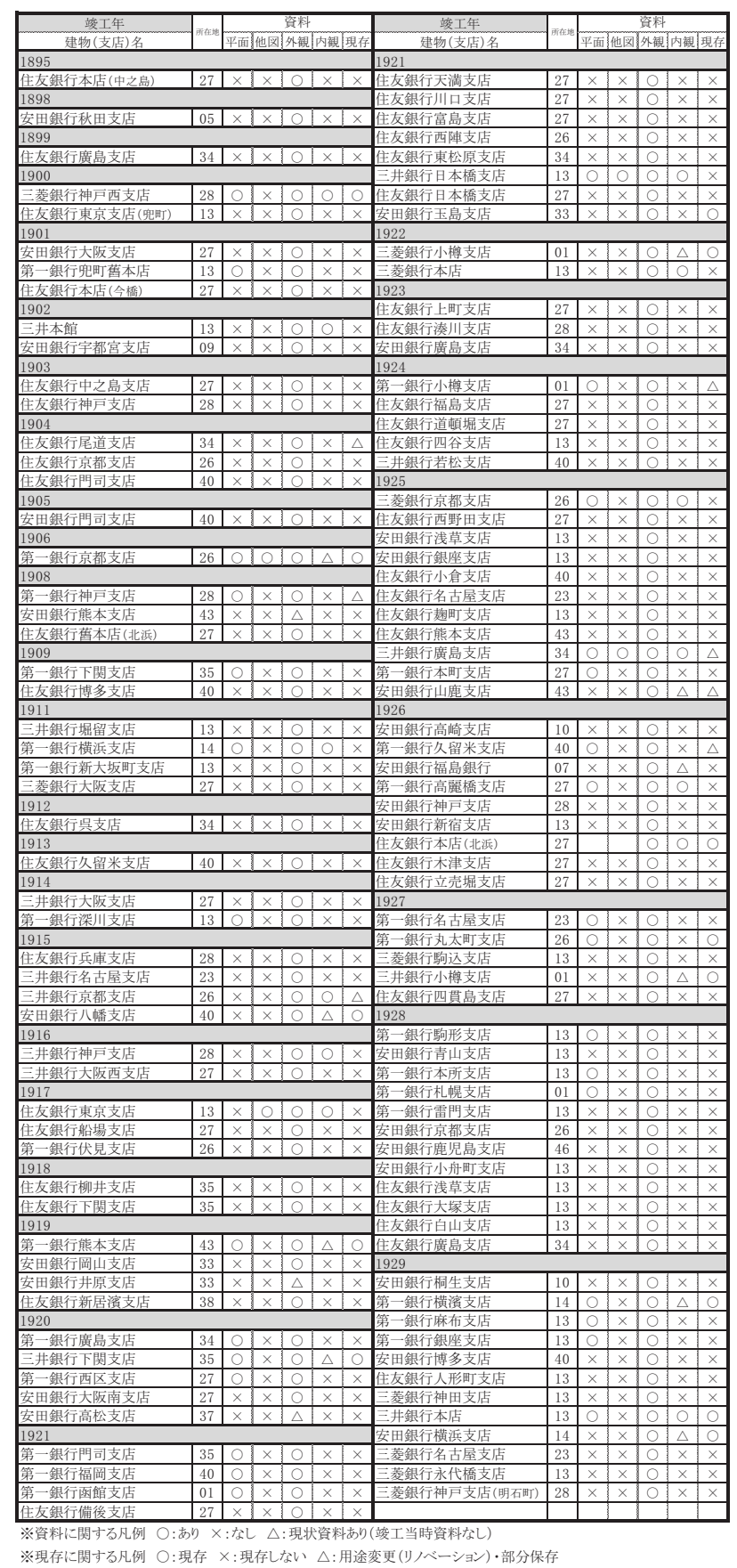


本研究では、1890〜1929 年の銀行建物の外観に着目して、どのよ うな建築要素が共通しているのかを調査分析することで初期の銀行 建物について考察する。明治政府による殖産興業政策の一環として 導入された西欧の（古典主義）様式建築は、おおむねヨーロッパ 19 世紀の折褁主義に属するとされている ${ }^{16)}$ 。明治政府が招聘した外国 人技師はすべて 19 世紀の建築界における折袁主義の技師であり ${ }^{16)}$ 、 来日した外国人建築家のなかで日本の近代建築に大きな影響を与え た J. コンドルについても「典型的な 19 世紀折襄主義建築家であっ て、その扱うモチーフは、初期ルネサンス、エリザベサン、ジャコ ビアン、ジョージアン、ヴィクトリアンそのほかに及び、これらを ほとんど自由に取捨し組合わせ整理して一つの建物にまとめあげ る。」 ${ }^{16)}$ とされている。したがって調査期間の銀行建物についても、 一つの建物の外観が統一された建築様式で構成されているとは限ら ない。また、明治・大正期の社会では建築の様式が認識されていた とは考え難く ${ }^{17)}$ 、銀行建物を見る側も様式を見ていたのではなく建 物の外観的な特徴を認識していたと推測する。よって本研究では、 古典様式から建物外観に関する建築要素を抽出して、銀行建物の事 例と照合する。その結果から、1890〜1929 年の銀行建物の外観に共 通する建築要素について考察することとする。なお、研究対象期間 における銀行建物の設計については、古典主義様式を取り入れるこ と、折禹主義でどのようにデザインするのかが設計の主要であると 考えられていた ${ }^{18)}$ 。よって、設計者の特定や分類、設計者の意匠的 な特徵等に関する調査は、本論の研究目的とは直接的な関連性が低 いため、本論では設計者を尺度とした調査は研究範囲に含めない。

\section{3. 建築要素の抽出と照合}

\section{1. 建築要素の抽出}

調查対象期間の国内建築および建築様式に関する文献 19）20) から、 調査期間の年代に確認されている建築様式を以下の通り抽出した。 ギリシャ様式、ローマ様式、バロック様式、ルネサンス様式、パラ ディアン様式、ジョージアン様式、アメリカン・ボザール様式、ジ ヤコビアン様式、エリザベサン様式、ゴシック様式、ビザンチン様 式、サラセン様式、チューダー様式、クィーン・アン様式、フリー・ クラシック様式、セセッション、アール・ヌーヴォー、ユーゲント・ シュティル、表現主義、モダニズム、無装飾主義を抽出した注4)。な お、復興様式（ネオ・ルネサンス様式、ネオ・バロック様式、ネオ・ ゴシック様式）については、もとの古典様式（ルネサンス様式、バ ロック様式、ゴシック様式）の建築要素の意匠的な派生（模倣や変 形）であることから、古典様式に含むものとした。また、研究対象 を銀行建物としていることから、住宅建築に関する建築様式につい ては抽出していない。抽出した建築様式から、調查期間の建築様式 に関する文献 19）20）、建築様式と建築要素に関する文献 21）22）および 調査対象の銀行建物（事例）をもとに、以下の銀行建物にかかわる 建築要素を抽出した。ペロン、ポルティコ（門型出入口）、オーダー

(ピラスター)、ペディメント（エディキュラ）、パラディアン空、 勾配屋根（マンサード、寄棟）、ルスティカ、ベースメント、コーニ ス（ストリングコース、モディリオン）、欄干、レリーフ（彫像、彫 刻）、アーチ（尖塔アーチ）、平屋根、切妻壁、ドーム、胸壁（パラ ペット、バトルメント、アチック)、隅櫓（塔）、アーチ、以上 17

Table 3 Architectural elements

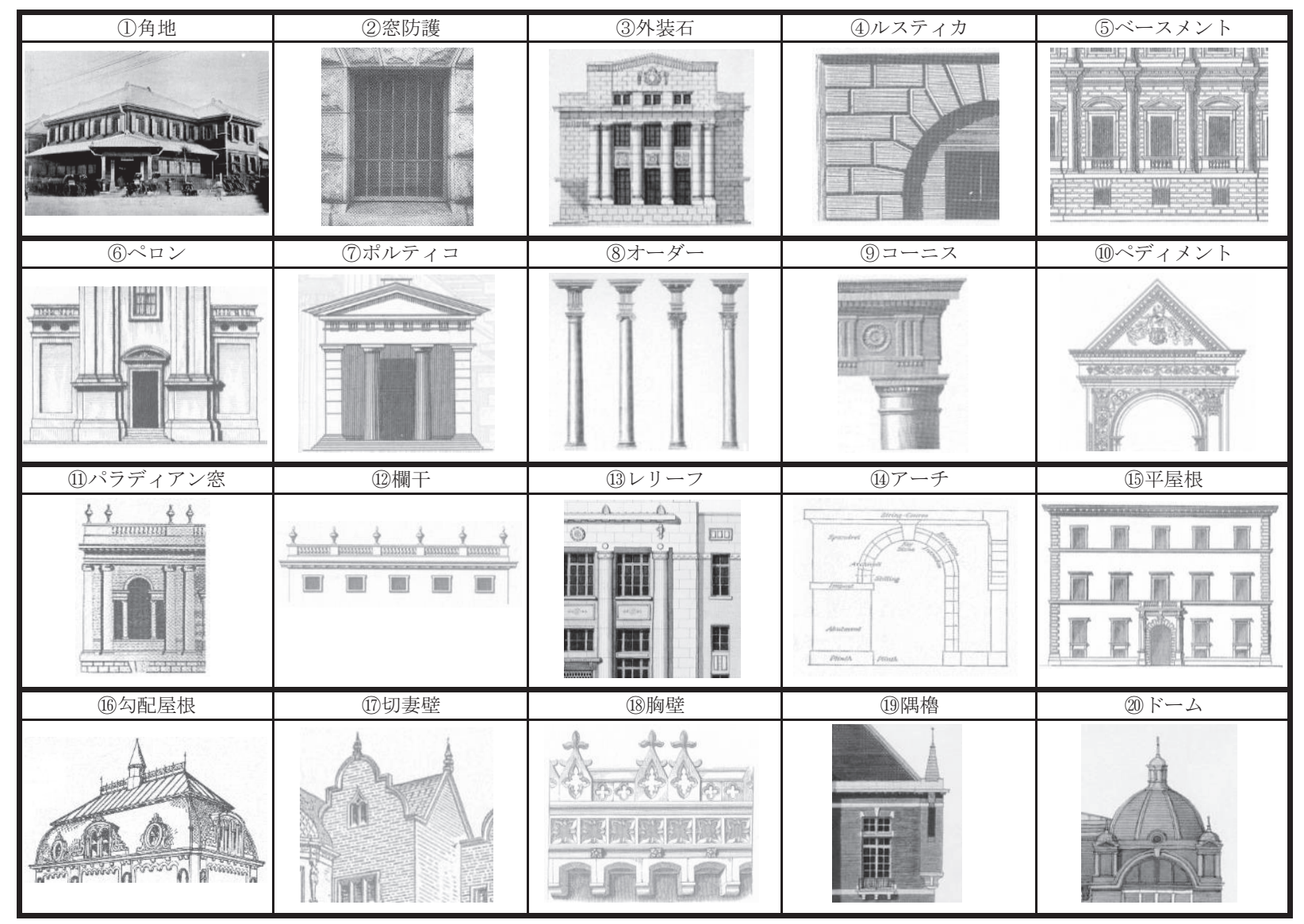


項目の建築要素（括弧内の要素を含む）を抽出した。なお、本研究 では国内の初期の銀行建物に共通する古典様式の建築要素を考察す るため、1920 年以降の近代建築運動から発生したセセッション、ア ール・ヌーヴォー、ユーゲント・シュティル、表現主義、モダニズ ム、無装飾主義からの建築要素の抽出はしていない。また、オーダ 一については、柱身と様式柱頭（ドリス、イオニア、コリント、ト スカーナ、コンポジット) の組合せを対象とする。

建築様式から抽出した建築要素と合わせて、銀行建物の外部に関 する機能的な要素として、角地、空防護（格子・鎧戸）、外装石の 3 項目を建築要素に加えた。角地については、葛西、西村が平面計画 と外観上の理由から銀行建物の敷地条件として角地の重要性を指摘 している $\left.{ }^{23)} 24\right)$ 。空防護は、銀行建物に特有の建築要素といえる。葛 西は、顧客に与えるイメージと建物の防犯箇所の優先順位などから 厳重な鉄格子は設置しない方が良いとしている ${ }^{23)}$ 。一方、西村は銀 行室の業務のために空防備を施した採光用空の必要性を指摘してい る ${ }^{24)}$ 。銀行建物の外装仕上げについては、銀行イメージの表現、銀 行としての防火性および都市計画上の防火区画として花崗岩などの 石材が好ましい25) とされていた。

以上、銀行建物の外観に関する建築要素として以下の (1)〜(20)（括 弧内の形状含む) を抽出して Table 3 に緾めた。(1)角地、(2)空防護 (格子、鎧戸)、(3)外装石、(4)ルスティカ、(5)ベースメント、(6)ペロ ン（門型出入口）、(7)ポルティコ、(8)オーダー（ピラスター)、(9) ーニス（ストリングコース、モディリオン）、(10)ペディメント（エデ イキュラ)、 (11)パラディアン空、(12)欄干（バルコニー手すり）、(13) レリーフ (彫像、彫刻)、(14)アーチ、(15)平屋根、16)勾配屋根（マンサ ード、寄棟)、(17切妻壁、(18胸壁（パラペット、バトルメント)、(19) 隅櫓（塔）、211゙ーム。

\section{2. 建築要素の照合}

(1)〜20の建築要素について、Table 2 の銀行建物事例 121 件と照 合して（例：Fig. 1)、建物外観における有無を確認した。事例数に 対する調查項目の採用数を「要素有の建物数 /照合建物数」として 20 項目の年別照合結果を Table 4 に䌂めた。なお、資料で確認でき ない調查項目については照合建物数から除外した。そして、Table 4 から建築要素ごとの 1890～1929 年の採用率の推移を Fig. 2、Fig. 3 に䌕めた。採用率の推移を分析するため、建築要素の採用数を 3 年 毎に集計した。但し 1890 年〜1899 年については事例数が 3 件のた め 1900 年に組み入れた。Fig. 2 に全体の採用率 $\geqq 50 \%$ 、Fig. 3 に全 体の採用率 $<50 \%$ （採用事例 0 の11 パラディン空は除外）の建築要 素について、採用率を時系列に纏めた。



Fig. 1 Verification of architectural elements. 注5)

Table 4 Result of contrast

\begin{tabular}{|c|c|c|c|c|c|c|c|c|c|c|c|c|c|c|c|c|c|c|c|c|c|}
\hline 年 & $\begin{array}{l}\text { 事例 } \\
\text { 数 }\end{array}$ & $\begin{array}{l}\text { (1) } \\
\text { 角地 }\end{array}$ & 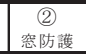 & $\begin{array}{c}\text { (3) } \\
\text { 外装石 }\end{array}$ & $\begin{array}{c}\text { (4) } \\
k \times \bar{T} \text { 仂 }\end{array}$ & $\begin{array}{l}\text { (5) } \\
\lambda^{2}-\lambda\end{array}$ & 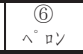 & 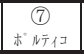 & $\begin{array}{c}8 \\
\text { (8) } \\
\text { (1) }\end{array}$ & $\begin{array}{c}9 \\
y-=x\end{array}$ &  & $\begin{array}{c}\text { (II) } \\
\text { (I) 害 }\end{array}$ & $\begin{array}{l}\text { (12) } \\
\text { 珹干 }\end{array}$ & $\begin{array}{c}\text { (13) } \\
(1)-7\end{array}$ & $\begin{array}{l}\text { (14) } \\
7-f-9\end{array}$ & $\begin{array}{c}\text { (15) } \\
\text { 平屋根 } \\
\end{array}$ & $\begin{array}{c}\text { (16) } \\
\text { 勾配矦相 }\end{array}$ & (17) & $\begin{array}{l}\text { (18) } \\
\text { 胸壁等 }\end{array}$ & 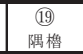 & (20) \\
\hline 1895 & 1 & - & $1 / 1$ & $0 / 1$ & $0 / 1$ & $1 / 1$ & $0 / 1$ & $0 / 1$ & $0 / 1$ & $0 / 1$ & $0 / 1$ & $0 / 1$ & $0 / 1$ & $0 / 1$ & $0 / 1$ & $0 / 1$ & $1 / 1$ & $0 / 1$ & $0 / 1$ & $0 / 1$ & $0 / 1$ \\
\hline 1898 & 1 & - & $1 / 1$ & $0 / 1$ & $0 / 1$ & $0 / 1$ & $0 / 1$ & $0 / 1$ & $0 / 1$ & $0 / 1$ & $0 / 1$ & $0 / 1$ & $0 / 1$ & $0 / 1$ & $0 / 1$ & $0 / 1$ & $1 / 1$ & $0 / 1$ & $0 / 1$ & $0 / 1$ & $0 / 1$ \\
\hline 1899 & 1 & $0 / 1$ & $0 / 1$ & $1 / 1$ & $1 / 1$ & $1 / 1$ & $1 / 1$ & $1 / 1$ & $1 / 1$ & $1 / 1$ & $0 / 1$ & $0 / 1$ & $1 / 1$ & $1 / 1$ & $1 / 1$ & $0 / 1$ & $1 / 1$ & $0 / 1$ & $0 / 1$ & $0 / 1$ & $0 / 1$ \\
\hline 1900 & 2 & $2 / 2$ & $1 / 2$ & $2 / 2$ & $1 / 2$ & $1 / 2$ & $1 / 2$ & $0 / 2$ & $1 / 2$ & $2 / 2$ & $2 / 2$ & $0 / 2$ & $1 / 2$ & $1 / 2$ & $2 / 2$ & $1 / 2$ & $1 / 2$ & $1 / 2$ & $1 / 2$ & $0 / 2$ & $0 / 2$ \\
\hline 1901 & 3 & $2 / 2$ & $2 / 3$ & $2 / 3$ & $1 / 3$ & $3 / 3$ & $2 / 3$ & $1 / 3$ & $2 / 3$ & $3 / 3$ & $2 / 3$ & $0 / 3$ & $0 / 3$ & $1 / 3$ & $2 / 3$ & $0 / 2$ & $2 / 2$ & $2 / 3$ & $1 / 2$ & $2 / 3$ & $1 / 3$ \\
\hline 1902 & 2 & $1 / 2$ & $1 / 2$ & $2 / 4$ & $1 / 2$ & $1 / 2$ & $2 / 2$ & $1 / 2$ & $0 / 2$ & $1 / 2$ & $1 / 2$ & $0 / 2$ & $1 / 2$ & $1 / 2$ & $1 / 2$ & $0 /$ & $2 / 2$ & $1 / 2$ & $1 / 2$ & $0 / 2$ & $1 / 2$ \\
\hline 1903 & 2 & $1 / 2$ & $0 / 2$ & $2 / 5$ & $1 / 2$ & $0 / 2$ & $1 / 1$ & $0 / 2$ & $1 / 2$ & $2 / 2$ & $1 / 2$ & $0 / 2$ & $0 / 2$ & $2 / 2$ & $2 / 2$ & $2 / 2$ & $0 / 2$ & $0 / 2$ & $2 / 2$ & $0 / 2$ & $0 / 2$ \\
\hline 1904 & 3 & $1 / 2$ & $3 / 3$ & $2 / 6$ & $2 / 3$ & $3 / 3$ & $3 / 3$ & $0 / 3$ & $2 / 3$ & $3 / 3$ & $1 / 3$ & $0 / 3$ & $0 / 3$ & $3 / 3$ & $2 / 3$ & $0 / 3$ & $3 / 3$ & $2 / 3$ & $1 / 3$ & $2 / 3$ & $1 / 3$ \\
\hline 1905 & 1 & $0 / 1$ & $1 / 1$ & $2 / 7$ & $0 / 1$ & $1 / 1$ & $0 / 1$ & $1 / 1$ & $0 / 1$ & $0 / 1$ & $0 / 1$ & $0 / 1$ & $0 / 1$ & $0 / 1$ & $0 / 1$ & $0 / 1$ & $1 / 1$ & $0 / 1$ & $0 / 1$ & $0 / 1$ & $0 / 1$ \\
\hline 1906 & 1 & $1 / 1$ & $1 / 1$ & $2 / 8$ & $0 / 1$ & $1 / 1$ & $1 / 1$ & $0 / 1$ & $0 / 1$ & $1 / 1$ & $1 / 1$ & $0 / 1$ & $1 / 1$ & $1 / 1$ & $1 / 1$ & $0 / 1$ & $1 / 1$ & $0 / 1$ & $0 / 1$ & $0 / 1$ & $0 / 1$ \\
\hline 1908 & 3 & $2 / 2$ & $1 / 3$ & $2 / 9$ & $0 / 3$ & $2 / 3$ & $2 / 3$ & $1 / 3$ & $2 / 3$ & $2 / 3$ & $2 / 3$ & $0 / 3$ & $0 / 3$ & $1 / 3$ & $2 / 3$ & $0 / 3$ & $3 / 3$ & $1 / 3$ & $1 / 3$ & $2 / 3$ & $2 / 3$ \\
\hline 1909 & 2 & $2 / 2$ & $0 / 2$ & $2 / 10$ & $1 / 2$ & $1 / 2$ & $2 / 2$ & $0 / 2$ & $2 / 2$ & $2 / 2$ & $1 / 2$ & $0 / 2$ & $0 / 2$ & $2 / 2$ & $1 / 2$ & $1 / 2$ & $1 / 2$ & $1 / 2$ & $2 / 2$ & $1 / 2$ & $0 / 2$ \\
\hline 1911 & 4 & $3 / 3$ & $2 / 4$ & $2 / 11$ & $1 / 4$ & $3 / 4$ & $4 / 4$ & $1 / 4$ & $3 / 4$ & $4 / 4$ & $2 / 4$ & $0 / 4$ & $3 / 4$ & $3 / 4$ & $3 / 4$ & $1 / 4$ & $3 / 4$ & $3 / 4$ & $3 / 4$ & $2 / 4$ & $2 / 4$ \\
\hline 1912 & 1 & $1 / 1$ & $0 / 1$ & $2 / 12$ & $0 / 1$ & $0 / 1$ & $1 / 1$ & $0 / 1$ & $0 / 1$ & $1 / 1$ & $0 / 1$ & $0 / 1$ & $1 / 1$ & $1 / 1$ & $1 /$ & $0 / 1$ & $1 / 1$ & $0 / 1$ & $0 / 1$ & $0 / 1$ & $0 / 1$ \\
\hline 1913 & 1 & - & $0 / 1$ & $2 / 13$ & $0 / 1$ & $0 / 1$ & $0 / 1$ & $0 / 1$ & $0 / 1$ & $0 / 1$ & $0 / 1$ & $0 / 1$ & $0 / 1$ & $0 / 1$ & $0 /$ & $0 / 1$ & $1 / 1$ & $0 / 1$ & $0 / 1$ & $0 / 1$ & $0 / 1$ \\
\hline 1914 & 2 & $2 / 2$ & $1 / 2$ & $2 / 14$ & $2 / 2$ & $2 / 2$ & $2 / 2$ & $0 / 2$ & $2 / 2$ & $2 / 2$ & $2 / 2$ & $0 / 2$ & $1 / 2$ & $2 / 2$ & $1 / 2$ & $1 / 2$ & $1 / 2$ & $0 / 2$ & $1 / 2$ & $0 / 2$ & $0 / 2$ \\
\hline 1915 & 4 & $3 / 4$ & 3 & $2 / 15$ & $2 / 4$ & $4 / 4$ & $4 / 4$ & $0 / 4$ & $4 / 4$ & $4 / 4$ & $1 / 4$ & $0 / 4$ & $0 / 4$ & $4 / 4$ & $1 / 4$ & $2 / 4$ & $2 / 4$ & $2 / 4$ & $4 / 4$ & $0 / 4$ & $1 / 4$ \\
\hline 1916 & 2 & $2 / 2$ & $1 / 2$ & $2 / 16$ & $1 / 2$ & $2 / 2$ & $2 / 2$ & $1 / 2$ & $2 / 2$ & $2 / 2$ & $1 / 2$ & $0 / 2$ & $1 / 2$ & $2 / 2$ & $0 / 2$ & $1 / 2$ & $1 / 2$ & $1 / 2$ & $2 / 2$ & $1 / 2$ & $2 / 2$ \\
\hline 1917 & 3 & $2 / 3$ & 21 & $2 / 17$ & $0 / 3$ & $1 / 3$ & $2 / 3$ & $1 / 3$ & $3 / 3$ & $3 / 3$ & $0 / 3$ & $0 / 3$ & $1 / 3$ & $3 / 3$ & $2 / 3$ & $2 / 3$ & $2 / 3$ & $0 / 3$ & $3 / 3$ & $0 / 3$ & $2 / 3$ \\
\hline 1918 & 2 & $0 / 2$ & $2 / 2$ & $2 / 18$ & $0 / 2$ & $0 / 2$ & $2 / 2$ & $0 / 2$ & $2 / 2$ & $2 / 2$ & $0 / 2$ & $0 / 2$ & $0 / 2$ & $2 / 2$ & $1 / 2$ & $2 / 2$ & $0 / 2$ & $1 / 2$ & $2 / 2$ & $1 / 2$ & $0 / 2$ \\
\hline 1919 & 4 & $2 / 3$ & $3 / 4$ & $2 / 19$ & $1 / 4$ & $3 / 4$ & $3 / 4$ & $1 / 4$ & $0 / 4$ & $3 / 4$ & $2 / 4$ & $0 / 4$ & $1 / 4$ & $2 / 4$ & $3 / 4$ & $2 / 4$ & $2 / 4$ & $1 / 4$ & $1 / 4$ & $1 / 4$ & $0 / 4$ \\
\hline 1920 & 5 & $\begin{array}{ll}3 / 3 \\
\end{array}$ & $2 / 5$ & $2 / 20$ & $1 / 5$ & $5 / 5$ & $5 / 5$ & $0 / 5$ & $5 / 5$ & $4 / 5$ & $2 / 5$ & $0 / 5$ & $1 / 5$ & $4 / 5$ & $4 / 5$ & $5 / 5$ & $0 / 5$ & $1 / 5$ & $4 / 5$ & $0 / 5$ & $0 / 5$ \\
\hline 1921 & 12 & $6 / 11$ & $6 / 12$ & $2 / 21$ & $5 / 12$ & $9 / 12$ & $11 / 12$ & $3 / 11$ & $7 / 12$ & 10/12 & $2 / 12$ & \begin{tabular}{|l|}
$0 / 12$ \\
\end{tabular} & \begin{tabular}{ll|}
$2 / 12$ \\
\end{tabular} & $9 / 12$ & $8 / 12$ & $10 / 12$ & $\begin{array}{l}2 / 12 \\
\end{array}$ & $2 / 12$ & $9 / 12$ & $\begin{array}{ll}0 / 12 \\
\end{array}$ & $1 / 12$ \\
\hline 1922 & 2 & $2 / 2$ & $2 / 2$ & \begin{tabular}{ll|}
$2 / 22$ \\
\end{tabular} & $1 / 2$ & $1 / 2$ & $2 / 2$ & $1 / 2$ & $2 / 2$ & $2 / 2$ & $1 / 2$ & $0 / 2$ & $0 / 2$ & $\begin{array}{ll}1 / 2 \\
\end{array}$ & $0 / 2$ & $2 / 2$ & $0 / 2$ & $0 / 2$ & $1 / 2$ & $0 / 2$ & $0 / 2$ \\
\hline 1923 & 3 & $2 / 3$ & $2 / 3$ & $2 / 23$ & $1 / 3$ & $2 / 3$ & $3 / 3$ & $0 / 3$ & $0 / 3$ & $3 / 3$ & $0 / 3$ & $0 / 3$ & $0 / 3$ & $2 / 3$ & $2 / 3$ & $3 / 3$ & $0 / 3$ & $1 / 3$ & $2 / 3$ & $0 / 3$ & $0 / 3$ \\
\hline 1924 & 5 & $4 / 5$ & $4 / 5$ & \begin{tabular}{ll|}
$2 / 24$ \\
\end{tabular} & $2 / 5$ & $5 / 5$ & $5 / 5$ & $1 / 5$ & $1 / 5$ & $4 / 5$ & $1 / 5$ & $0 / 5$ & $1 / 5$ & $3 / 5$ & $3 / 5$ & $3 / 5$ & $2 / 5$ & $0 / 5$ & $1 / 5$ & $0 / 5$ & $0 / 5$ \\
\hline 1925 & 11 & $11 / 11$ & $11 / 11$ & $2 / 25$ & $3 / 11$ & $7 / 11$ & 10/11 & $1 / 11$ & $6 / 11$ & $1 / 11$ & $3 / 11$ & $0 / 11$ & $3 / 11$ & $8 / 11$ & $6 / 1$ & $10 / 11$ & \begin{tabular}{ll|}
$1 / 11$ \\
\end{tabular} & $0 / 11$ & $5 / 11$ & $0 / 11$ & $0 / 11$ \\
\hline 1926 & 9 & $8 / 9$ & $6 / 9$ & $2 / 26$ & $4 / 9$ & $5 / 9$ & $9 / 9$ & $1 / 9$ & $7 / 9$ & $8 / 9$ & $5 / 9$ & $0 / 9$ & $1 / 9$ & $5 / 9$ & $5 / 9$ & $7 / 9$ & $1 / 9$ & $0 / 9$ & $2 / 7$ & $0 / 9$ & $0 / 9$ \\
\hline 1927 & 5 & $5 / 5$ & $3 / 5$ & $2 / 27$ & $1 / 5$ & $4 / 5$ & $4 / 5$ & $0 / 5$ & $1 / 5$ & $5 / 5$ & $0 / 5$ & $0 / 5$ & $1 / 5$ & $4 / 5$ & $4 / 5$ & $4 / 5$ & $1 / 5$ & $0 / 5$ & $1 / 5$ & $0 / 5$ & $0 / 5$ \\
\hline 1928 & 12 & $9 / 12$ & $8 / 12$ & $2 / 28$ & \begin{tabular}{ll|}
$1 / 12$ \\
\end{tabular} & $6 / 12$ & $\begin{array}{l}9 / 10 \\
\end{array}$ & $1 / 12$ & $8 / 12$ & $12 / 12$ & $2 / 12$ & \begin{tabular}{|l|}
$0 / 12$ \\
\end{tabular} & $\begin{array}{ll}0 / 12 \\
\end{array}$ & $8 / 12$ & $7 / 12$ & $12 / 12$ & $0 / 12$ & $0 / 12$ & $6 / 12$ & \begin{tabular}{ll|}
$1 / 12$ \\
\end{tabular} & $0 / 12$ \\
\hline 1929 & 12 & \begin{tabular}{|l}
$11 / 12$ \\
\end{tabular} & $8 / 12$ & $2 / 29$ & \begin{tabular}{|l|l|}
$7 / 12$ \\
\end{tabular} & $10 / 12$ & $12 / 12$ & $1 / 12$ & $11 / 12$ & $12 / 12$ & $5 / 12$ & \begin{tabular}{|l|l}
$0 / 12$ \\
\end{tabular} & $1 / 12$ & $7 / 12$ & $6 / 12$ & $12 / 12$ & $0 / 12$ & $0 / 12$ & $6 / 12$ & $0 / 12$ & $0 / 12$ \\
\hline 合計： & 採用数 & $88 / 110$ & $78 / 121$ & \begin{tabular}{|l|}
$90 / 121$ \\
\end{tabular} & $41 / 121$ & \begin{tabular}{|l|}
$84 / 121$ \\
\end{tabular} & $105 / 118$ & \begin{tabular}{|l|l|}
$18 / 120$ \\
\end{tabular} & $75 / 121$ & \begin{tabular}{|c|}
$99 / 121$ \\
\end{tabular} & $40 / 121$ & $0 / 121$ & 22/121 & $83 / 121$ & 71/121 & $83 / 120$ & $37 / 120$ & $20 / 121$ & $62 / 119$ & $13 / 121$ & $13 / 121$ \\
\hline $\begin{array}{l}\text { 採用 } \\
\end{array}$ & 紊\% & 80.0 & 64.5 & \begin{tabular}{|l|l|}
74.4 \\
\end{tabular} & 33.9 & 69.4 & 89.0 & 15.0 & 62.0 & 81.8 & 33.1 & 0.0 & 18.2 & 68.6 & 58.7 & 69.2 & 30.8 & 16.5 & 52.1 & 10.7 & 10.7 \\
\hline
\end{tabular}




\section{4. 考察}

調查対象とした 1890 年から 1929 年に建設された五銀行の建物に ついて、機能的な要素を含む様式に関する 20 項目の建築要素の有無 を照合した結果について Table 4 およびFig. 2, Fig. 3 をもとに考察 する。

\section{1. 考察 1}

Table 4 より、全体での採用率の順位は次の通り。1（6)ペロン、 2. (9)コーニス、3. (1)角地、4. (3)外装石、5. (5)ベースメント、6. (15) 平屋根、7. (13)レリーフ、8. (2)空防護、9. (8)オーダー、10。 (14)アー チ、11. (18)胸壁、12. (4)ルスティカ、13. (10ペディメント、14. (16) 勾配屋根、15. (12)欄干、16. (17)切妻壁、17. (7)ポルティコ、18. (19) 隅櫓・(20)ドーム、20. (11)パラディアン空、の順である。採用率でみ た場合、角地、ペロン、コーニスは全体の $80 \%$ 以上で、外装石は全 体の $70 \%$ 以上の銀行建物で採用されている。また、空防護、ベース メント、オーダー、レリーフ、平屋根は全体の $60 \%$ 以上、アーチと 胸壁は全体の $50 \%$ 以上の銀行建物で採用されている。

Fig. 2 より、(1)〜20建築要素の採用率の推移に関する考察は以下 の通り。(1)角地は 1900 1929 年の間つねに $50 \%$ 以上、1911 年以降 は 60\%以上で推移している。(2)空防護は 1917 年までは採用率に変 化（増減）があるが、1917 年以降は $60 \%$ 以上（1923 年のみ $58.8 \%)$ で推移している。(3)外装石は 1903 年のみ $50 \%$ 以下となるが、比較 的安定した増加傾向で 1923 年以降は 70\%以上で推移している。(5) ベースメントは 1900～1929 年の間つねに 50\%以上、1917 年以降は 60\%以上で推移している。(6)ペロンは、1903 年以降つねに 70\%以上、

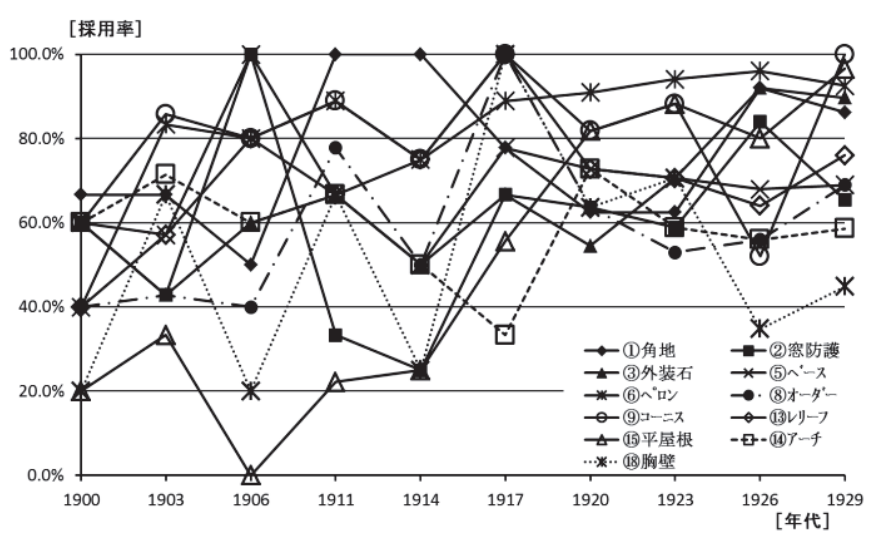

Fig. 2 Transition graph of architectural elements I



Fig. 3 Transition graph of architectural elements II
1914 年以外は $80 \%$ 以上で推移している。8オーダーは 1911 年以降 $50 \%$ で推移しているが、増減の変化があり、1917 年以外は $70 \%$ を超 えていない。9コーニスは 1926 年以外つねに 60\%以上で、ペロン ンに次いで安定的に推移している。(13)レリーフは 1906〜1929 年の間 $60 \%$ 以上で推移している。(15)平屋根は 1906 年以降増加傾向となり、 1920 年以降は $80 \%$ 以上で推移している。Fig. 3 の囵勾配屋根とは逆 相関を示している。(14)アーチは 1914〜1917 年に 50\%以下となる以 外は、60\%前後で推移している。18胸壁は 1900～1929 年の間 20〜 $100 \%$ で増減が連続している。そして全体としては 1920 年以降、(1) 角地、(2)空防護、(3)外装石、(5)ベースメント、(6)ペロン、8オーダ 一、(9)コーニス、(13)レリーフ、(11)平屋根、(14)アーチの建築要素は、 およそ $60 \%$ 以上（囵アーチのみ 56.0 ～58.8\%）の銀行建物の外観に 共通寸る傾向で収束していることが示された。また Fig. 3 より、1920 年以降、(7)ポルティコ、(12)欄干、(16)勾配屋根、(17)切妻壁、(19)隅櫓、 (20)ドームの建築要素は、銀行建物での採用率が 30\%以下、(4)ルステ ィカと(10ペディメントは 40\%以下の傾向で収束している。

以上より、角地、窓防護、外装石、ベースメント、ペロン、オー ダー、コーニス、レリーフ、平屋根、アーチの建築要素が 1920 年前 後から銀行建物の外観に共通寸るようになったと考えられる。

\section{2. 考察 2}

古典様式では、コーニスはオーダーを構成するベース、コラム、 エンタブラチュアの中の一つの建築要素とされている。そして本来 はオーダーのシステムの一部として建物の外観に用いられる建築要 素である。しかし照合調査結果（Table 4）では、コーニスの採用率 (81.8\%) とオーダーの採用率 $(62.0 \%)$ に 19.8 ポイント差がある。 寸なわち $19.8 \%$ の銀行建物では、コラムはないがコーニスが採用さ れていることになる。この点から、コーニスは従来の様式のシステ ムの一部ではなく、エンタブラチュアとは切り離されて単独で外観 に採用されていたことが示された。ちなみに古代エジプト建築様式 のコーニスは、「神殿の壁や塔門の頂上に沿って造られる、突き出し

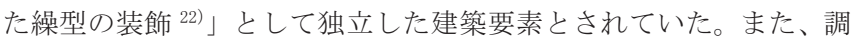
查対象とした銀行建物の $50 \%$ 以上の外観に共通する建築要素のう ち銀行の機能面から抽出した 3 要素以外のペロン、オーダー、ベー スメント、コーニス、レリーフ、平屋根、アーチ、胸壁の 8 要素に ついては、クラシック様式、ルネサンス様式、ゴシック様式の建築 要素である。銀行建物の外観に共通する建築要素に関して、特定の 様式から抽出されている傾向はみられないと考えられる。

以上より、折襄主義とされる明治・大正期の銀行建物では、建築 様式だけではなく建築要素についても取捨し組み合わせ整理されて つくられていたことが示された。

\section{3. 考察 3}

全体の $60 \%$ 以上の銀行建物で採用されていた建築要素 9 項目に関 して、照合調查過程および照合結果（Table 4,Fig. 2，Fig. 3）より 以下の考察をした。角地については、葛西、西村らが銀行建物の敷 地条件として角地の重要性を提言している。果たして設計者だけで はなく、建築主である銀行でも角地に店舗を建設することによる平 面計画と銀行業務・営業への影響および街並みにおける外観（銀行 の広告効果）など、その機能面での重要性を認識していたと考えら れる。空防護は、銀行業が社会的に認識されたことで必要となった 銀行特有の防犯機能としての建築要素といえる。空防護の是非につ 
いては設計者によって意見が分かれている。銀行建物では、機能的 な建築要素である空防護が、建物外観全体と整合させるために意匠 性が考慮されるようになったと考えられる。建物外装石は、防火性・ 防犯性・耐久性の機能的な目的と、重厚、信頼感などの銀行イメー ジを表現する意匠的な目的をもった建築要素であったといえる。自 然石仕上げではない銀行建物では、煉瓦、タイル貼り、煉瓦やタイ ルと石の組合せなどの外装が確認された。ベースメントは本来地階 が地上部に表出した部分であるが、調査では地階がない銀行建物で も形状として確認された。営業室内側の腰壁高さを確保（内装保護 と防犯）することにより、結果的に前面道路に対する防犯と建物を 保護する機能性がベースメントに付加されたことが、採用されるよ うになった一因に考えられる。銀行建物のアプローチについて西村 は、顧客が入りやすいように玄関入口には階段が全くないことがよ いとしている ${ }^{24)}$ 。しかし調査では、道路の砂塵や泥注 6) などが建物 内一流入寸るのを防ぐ機能と、顧客が最初に接触する空間（威㛜を 表現する）の意匠として、門型と数段の階段とプラットフォームで 構成されたペロンが確認された。古典様式のオーダーでは柱身柱頭 とエンタブレチュアは不可分とされているが、調查対象の銀行建物 では柱身柱頭のみや、半円柱、ピラスターの設置が確認された。柱 身柱頭については、様式規定の建築オーダー26) とは異なる比例形状 や、建物全体の様式や意匠とは合致しない柱身柱頭も確認された。 また建物の規模にかかわらず採用されていて、構造上の柱としてで はなく意匠的な建築要素として採用されていることが確認された。 調查対象の銀行建物では、オーダーを構成する建築要素としてのコ ーニスと、オーダーとは切り離された建物頂部の突出したコーニス やストリングコース (同蛇腹) などが確認された。オーダーと切り 離されたコーニスは、建物の外壁を保護するための水切り（笠木） という機能的な建築要素として採用されていたと考えられる。レリ ーフはペディメントのティンパヌムやアーキトレーブだけではなく、 出入口や開口部の周り、切妻壁や外壁面に確認された。レリーフの デザインは、古典様式のモチーフや企業に関連するモチーフが確認 された。また、ブルズアイ、欄干やコーニスの上部の彫像や壶の装 飾なども確認された。調查建物の平屋根は、コーニス、欄干、胸壁 などと組み合わせて採用されている事例が確認された。外観資料に よる照合のため、ごく緩い勾配の屋根（見えない場合）は平屋根と して検証している。平屋根は、建築技術の変化に伴う防水機能、銀 行建物の外観全体に影響する意匠的な建築要素として採用されてい たと考える。なお Fig. 2, Fig. 3 から、平屋根は勾配屋根の採用率と 負の相関関係の傾向が示された。

全体の $60 \%$ 以上の銀行建物で採用されていた建築要素 9 項目のう ち、オーダーとレリーフの 2 項目は装飾性以外に建築的な機能性を 持たない建築要素といえる。その他の建築要素 7 項目のうち角地、 空防護、外装石は銀行業務の機能的な建築要素として調查対象とし たものである。そしてペロン、コーニス、ベースメント、平屋根の 4 項目については、それぞれ様式としてのかたち（装飾性）だけで はなく、銀行建物における機能性を兼備している建築要素といえる。 1890～1929 年の銀行建物に共通する建築要素については、様式的な かたち（装飾性）と機能を併せもっていたことが共通の建築要素と なった（60\%以上の銀行建物で採用された）一つの要因ではないか と考察する。それらの要因については、今後の検証課題である。

\section{5. 結論}

\section{1. 銀行建物の外観に共通する建築要素}

明治期の古典主義様式の建築は折襄主義とされることから、本論 では古典主義様式から建物外観を構成する建築要素を抽出して、 1890〜1929 年に建設された五大銀行の建物と照合して、銀行建物に 共通する建築要素について検証した。

その結果、角地、空防護、外装石、ベースメント、ペロン、オー ダー、コーニス、レリーフ、平屋根が $1890 \sim 1929$ 年の五大銀行の 60\%以上の建物に共通する建築要素であることを明らかにした。ま たアーチについても $58 \%$ 以上の銀行建物に共通する建築要素であ ることを明らかにした。そしてそれらの建築要素は、1920 年前後か らおよそ 6 割以上の銀行建物の外観に見られるようになったことが 明らかになった。

またオーダーとコーニスに関する調査結果からは、調查期間の銀 行建物では建築様式の折衷だけではなく、建築様式を構成する建築 要素についても、個別に取捨、組合せ、整理されて、銀行建物の外 観がつくられていることが確認された。

銀行業における調查期間の五銀行の影響力を考えると、銀行建物 についても他の国内の銀行建物に影響をおよぼしたと推測される。

\section{2. 今後の課題}

本論の結論を踏まえて今後の課題を摘記する。

本論では、国内の初期の銀行建物とはどのような建物であったの かを明らかにするために、1890〜1929 年に建設された銀行建物の外 観に着目して、共通する建築要素をについて検証した。本論では、 はじめに研究対象を五銀行（三井、三菱、安田、住友、第一）の範 囲に設定したが、五銀行以外の普通銀行および普通銀行以外 (種別) の銀行（国立、特殊、農工、貯蓄）建物を研究対象に含めた検証が 必要である。また、銀行建物の外観に関する五銀行ごとの特徴、共 通点や相違点などの調查・分析、銀行の種類別の調查・分析、銀行 建物の設計者を尺度に加えた調查・分析も今後の課題といえる。

本論で明らかにした 1890〜1929 年の銀行建物に共通する建築要 素が、1930 年以降どのように変化したのか、1930 年以降の銀行建物 に共通する建築要素を含めた検証が必要である。また、必ずしも銀 行建物に独自の建築要素であるとは限らない銀行建物に共通する建 築要素が、1950 年代以降の銀行らしい建物のイメージとどう関係す るのかを検証すること。そのために、同時期の他用途の建物にある 建築要素とその 1930 年以降の変化について、銀行建物の建築要素と の比較を含めた検証が必要である。

また、銀行建物に共通する建築要素に関する要因、なぜ共通する ようになったのかを明らかにすること。建物の目的である銀行業務 の変化が銀行建物のかたちにどのような影響を及ぼすのか、銀行制 度を含めた銀行業務や銀行の社会的役割の変化と銀行建物の変化の 関係を検証することが必要である。さらに、銀行建物の変化と建築 技術や建築文化の変化、地域性との関係など重層的多面的な調查・ 分析も今後の課題である。

以上の課題を検証することにより、1872 年から現在に至る銀行建 物の通史的な変遷を明らかにしたい。 
1）田中誠：銀行とその建築，銀行店舗 第一巻, pp. 184-189, 近代セールス 社, 1964.6

2）曾爾達蔵, 葛西萬司, 池田稔: 建築世界, 第九巻第四号, 現代模範建築銀 行会社号, pp. 10-23, pp. 37-40, 建築世界社, 1915.4

3）銀行 7 題：建築文化， 1953 年 10 月号 Vol. 84，pp. 24-25，1953. 10 銀行店舗の明日一の課題（座談会：石川留已之, 飯野公一, 玉川陽太郎, 塩原祐三郎）：銀行店舗 第一巻, pp. 196-202, 近代セールス社, 1964.6

4）溝口正人, 向口武志, 柳澤宏江 : 愛知県下における明治末 ·大正の銀行建 8 築の意匠, 日本建築学会東海支部研究報告集, 第 49 号, pp. 705-708, 2011.2

5）西澤泰彦: 建築家中村與資平の経歴と建築活動について, 日本建築学会計 画系論文報告集，第 450 号, pp. 151-160，1993.8

6) 駒木定正 : 日本銀行小樽支店 (明治 45 年) の主要構造と仕様, 日本建築学 会計画系論文集，第 471 号, pp. 139-146, 1995.5

片野博：旧報徳銀行直方支店の構造 - 構法的特徵, 日本建築学会計画系論 文集，第 482 号，pp. 85-94，1996. 4

7）曾根陽子, 安藤真由子: 銀行建物の用途変更に関する研究, 日本建築学会 技術報告集，第 15 巻，第 31 号，pp. 855-858，2009. 10

8）志水英樹, 谷口汎邦, 宮本文人 : 大都市において銀行建築が構成する街並 の物的属性について, 日本建築学会計画系論文報告集, 第 375 号, pp. 64-75, 1987.5

9）阿部和俊 : 1896 年-1940 年におけるわが国の銀行支店網について, 経済地 理学年報，第 26 巻 第 2 号, pp. 78-91，1980.9

吉津直樹 : 明治期〜第二次大戦前における金融網の地域的展開過程一「五大 銀行」を中心として-, 経済地理学年報, 第 26 巻 第 2 号, pp. 57-77, 1980.9

10）東京銀行協会図書館（世良裕一）：わが国銀行の歴史と変遷（第 1 回： 明治・大正期），金融，732 号，pp. 49-62，全国銀行協会，2008.4 東京銀行協会図書館（世良裕一）：わが国銀行の歴史と変遷（第 2 回：昭 和初～ 20 年 8 月），金融， 733 号，pp. 35-44，全国銀行協会，2008. 5

11）後藤新一：日本の金融統計，pp. 89-91，東洋経済新報社，1960.7 そのほか各銀行史、三井銀行八十年史（1957. 11）、三菱銀行史（1954.8） 住友銀行史 (1955.11) において五大銀行の表記あり。

12）（社）全国銀行協会 銀行図書館，銀行変遷史データベース

三井銀行 $\rightarrow 1990.4$ 太陽神戸三井銀行 $\rightarrow 1992.4$ さくら銀行 $\rightarrow 2001.4$ 三井住 友銀行

安田銀行 $\rightarrow 1948.10$ 富士銀行 $\rightarrow 2002.4$ みずほ銀行

第一銀行 $\rightarrow 1981.10$ 第一勧業銀行 $\rightarrow 2002.4$ みずほ銀行

三菱銀行 $\rightarrow 1996.4$ 東京三菱銀行 $\rightarrow 2006.1$ 三菱東京 UFJ 銀行

住友銀行 $\rightarrow 2001.4$ 三井住友銀行

13）吉津直樹: 明治期〜第二次大戦前における金融網の地域的展開過程 -「五 大銀行」を中心として - , 経済地理学年報, 第 26 巻 第 2 号, p. 58, 1980.9

14）三井銀行内 小林忠太郎：三井銀行五十年史, 三井銀行, 1926.9

三井銀行八十年史編纂委員会 : 三井銀行八十年史, 三井銀行, 1957. 11

三菱銀行史編纂委員会 : 三菱銀行史，三菱銀行，1954.8

住友銀行史編纂委員会 : 住友銀行史, 住友銀行, 1955. 11

住友銀行：住友銀行創立四十周年記念写真帖，住友銀行，1935.11

安田銀行六十周年記念事業委員会 : 安田銀行六十年誌, 安田銀行, 1940.9 第一銀行内 長谷井千代松：第一銀行五十年小史，第一銀行，1926.8

第一銀行八十年史編纂室 : 第一銀行史（上下巻），第一銀行，1958.

15）高梨由太郎：建築寫眞類聚 銀行會社, 巻一・二・四・六, 洪洋社, 1916. 4

$\sim 1926.9$

西村好時：銀行建築，丸善，1933.12

中村勝哉：西村好時作品譜，城南書院，1950.11

長谷部竹腰建築事務所：長谷部竹腰作品集，城南書院，1943.11

第一銀行 小見波隆朔：株式会社第一銀行，第一銀行，1930.11

第一銀行八十年史編纂室 : 第一銀行史（上下巻），第一銀行， 1958 .

鈴木荘太郎, 演松義雄 : 長野博士作品集, 建築世界社, 1928.7

村松貞次郎，藤森照信：日本の建築［明治大正昭和］3，三省堂，1979.2

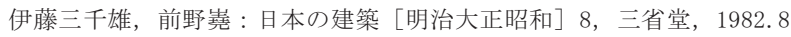
辰野金吾，葛西萬司：家屋建築實例第壹巻之圖，須原屋書店，1908.9, 日本建築学会図書館デジタルアーカイブス：辰野文庫,

http://www. aij. or. jp/da1/bunko/pdf/J7010597_01.pdf（参照 2016-3-10） 神奈川県立歴史博物館 : 彩色立面図に見る日本の近代建築 - 銀行・オフィ スビルから邸宅まで - , 2010.2

清水建設株式会社ホームページ：清水建設二百年作品集,

http://www. shimz. co. jp/200th/sakuhin/200-sakuhin-n18811914. html,
(参照 2016-4-22)

鈴木博之, 初田亨 : 図面でみる 都市建築の明治, 柏書房, 1990.4

16）稲垣栄三: 日本の近代建築, p. 18, p. 78, p. 66, 中央公論美術出版, 2009.9

17）田中實：現今の銀行會社建築の實際，建築世界，第九巻第四号，現代模 範建築銀行会社号, pp. 57-65, 建築世界社，1915.4，「要するに注文者と 云ふものは現今の所では建築の眼のない故に、何うしても世の中一般が進 んで來て建築思想を持って來てくれなくては困る。」と述べている。

18）曾禰達藏：銀行會社の建築に就て，建築世界，第九巻第四号，現代模範 建築銀行会社号, p. 14，建築世界社，1915.4，

葛西萬司：銀行の建物，建築世界，第九巻第四号，現代模範建築銀行会社 号, p. 17，建築世界社，1915.4，

池田稔 : 銀行會社の外觀，建築世界，第九巻第四号，現代模範建築銀行会 社号, p. 40, 建築世界社, 1915.4,

稲垣栄三 : 近代建築史研究, p. 23, 28, 中央公論美術出版, 2007.6

稲垣栄三：日本の近代建築, pp. 85-87, 中央公論美術出版, 2009.9 藤森照信：日本の近代建築（上）-幕末・明治篇-, pp. 224-235，岩波書店， 1993. 10

藤森照信 : 日本の近代建築 (下) -大正・昭和篇-, pp. 4-52, 岩波書店, 1993. 11

19）桐敷真次郎：明治の建築, pp. 61-170, 本の友社, 2001.4

稲垣栄三：日本の近代建築，四 明治時代の建築，pp. 57-95, 中央公論美術 出版, 2009. 9

稲垣栄三 : 近代建築史研究, pp. 7-27, 中央公論美術出版, 2007.6 村松貞次郎：日本近代建築の歴史，pp. 78-99、126-159，岩波書店，2005.4 藤森照信：日本の近代建築（上）-幕末・明治篇-，岩波書店，1993.10

20）太田博太郎, 藤井恵介 : 日本建築様式史, pp. 130-149, 美術出版社, 1999.8 鈴木博之，五十嵐太郎，横手義洋：近代建築史，pp. 98-128、154-170，市 ヶ谷出版社, 2008. 10

21）村松貞次郎：日本の様式建築（新建築 1976 年 6 月臨時増刊）, 様式建築 再考, 新建築社, 1976.6

22) エミリー・コール：世界の建築様式 (A Concise History of Architectural Styles)，ガイアブックス平野陽三，2009.10

23）葛西萬司：建築世界，第九巻第四号，現代模範建築銀行会社号，銀行の 建物，p. 19，建築世界社，1915.4

24）西村好時：銀行建築，第二章 銀行建築，p. 16、28, 丸善，1933. 12

25）西野蕙之助, 池田稔, 大熊喜邦ほか：建築世界，第九巻第四号，現代模 範建築銀行会社号，建築世界社，1915.4

26）長尾重武: G・B ヴィニョーラ 建築の五つのオーダー, pp. 3-33, 中央公 論美術出版，1984.1，ヴィニョーラによる 5 つのオーダーシステムの解説

注

注 1）研究対象として銀行法の施行の 1928 年時点で設計または着工されてい た銀行建物を含めるため、工事期間を考慮して 1929 年竣工・開業までを画 期とした。

注 2）後藤新一：日本の金融統計，表 30 の 1 全国普通銀行主要勘定，表 31 の 1 五大銀行主要勘定, pp. 86-91, 東洋経済新報社, 1960.7 上記資料をもとに以下は筆者纏め。

\begin{tabular}{|c|r|r|r|r|}
\hline 年 & \multicolumn{2}{|c|}{ 全国普通銀行 } & \multicolumn{2}{|c|}{ 五大銀行 } \\
\cline { 2 - 5 } & 総預金 & 貸出金 & 総預金 & 貸出金 \\
\hline 1900 & 437 & 662 & 78 & 77 \\
\hline 1910 & 1,186 & 1,250 & 255 & 215 \\
\hline 1920 & 5,827 & 5,903 & 1,570 & 1,236 \\
\hline 1929 & 9,292 & 7,246 & 3,210 & 2,013 \\
\hline
\end{tabular}

注 3）国内銀行の銀行数と銀行店舗数については、日本銀行統計局：明治以 降 本邦主要経済統計， 64、65 全国銀行主要勘定，66 私立・普通銀行主要 勘定， 67 貯蓄銀行主要勘定、68 特殊銀行主要勘定，pp. 194-205，から国内 銀行数を調查。合わせて横浜正金銀行、日本勧業銀行の店舗数は各銀行史 から、農工銀行の店舗数は一県一行として国内銀行の店舗数を調査算出。 五銀行の店舗数および調査期間の開業店舗については、参考文献 13）五銀 行の銀行史の本文、文中資料、年表より調査。

注 4）第一銀行 横濱支店，1911 年 6 月竣工，設計：清水組・北村耕造，施工： 清水組, 建築寫眞類聚 銀行會社 巻一, p. 27, 洪洋社, 1916.4 注 5）総務省統計局：12-4 道路延長及び舗装道路（明治 27 昭和 10 年）よ り。日本における本格的な道路の近代化計画は道路法が制定される 1919 年 からで、1936 年時点での国道舗装率は $13.9 \%$ 、都道府県道と市町村道を合

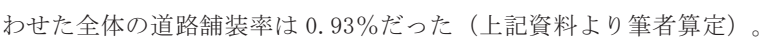


A STUDY ON BANK BUILDINGS CONSTRUCTED BETWEEN 1890 AND 1929

Common architectural elements in the external appearances of the buildings of Japan's five major banks

\section{Hiroshi NAKAMURA* and Michihiko SHINOZAKI**}

* Grad. Stud., Graduate School of Engineering and Science, Shibaura Institute of Technology, M. M.O.T.

** Prof., Dept. of Engineering and Design, Shibaura Institute of Technology, Dr.Eng.

The history of bank buildings in Japan commenced with the establishment of the First National Bank in 1872.To date, only minimal research on the historical changes in the bank buildings constructed between 1872 and present day has been conducted.

Focusing on building exteriors, this study aims to examine the common architectural elements in the bank buildings constructed between 1890 and 1929. This study serves as an introductory account of the historical changes in the bank buildings constructed between 1872 and present day. The Western European-style architecture introduced by the Meiji-period policy belonged to the 19th-century European eclecticism.

Therefore, no building in that period was constructed in a unified architectural style.

This eclectic architectural style was possibly not appreciated by the Meiji-period society. It can be presumed that people who looked at bank buildings did not look at the architectural style but rather appreciated distinct parts of the buildings' exterior.

Therefore, this study extrapolates the architectural elements of the exteriors of the buildings constructed in the classical style and contrasts these elements with examples of such bank buildings.

Thereafter, on the basis of the results, this study discusses the common architectural elements in the bank buildings constructed between 1890 and 1929.

The buildings of the five major banks in Japan (Mitsui, Mitsubishi, Sumitomo, Yasuda, and Daiichi) constitute the research subjects of this study. The period chosen ranges from 1890 (when commercial banking started) to 1929 (after the Order for Enforcement of the Banking Act). Herein, 20 different architectural elements related to the exteriors of 121 individual buildings were examined and the architectural elements common in the exteriors of various buildings were analyzed.

The results reveal that corner lots, window grilles and railings, exterior stone, basements, perrons, architectural orders, cornices, reliefs, and flat roofs are found in over $60 \%$ of the buildings.

Considering the understanding of historical design and trends that it offers, this study can serve as a guideline for the construction of future bank buildings with new, creative designs. 